\title{
Opinions on mental illness from the perspective of primary care nurses in Portugal
}

\author{
Opiniões frente à doença mental na perspectiva de \\ enfermeiros de cuidados primários em Portugal \\ Comentarios sobre la enfermedad mental desde la perspectivas \\ de las enfermeras de atención primaria en Portugal \\ Carla Silvia Neves da Nova Fernandes ${ }^{a}$ \\ Wallace Borges Costa dos Santos ${ }^{b}$ \\ Wanderson Carneiro Moreira ${ }^{b}$ \\ Divane de Vargas ${ }^{\mathrm{b}}$ \\ Maria do Perpétuo Socorro de Sousa Nóbrega ${ }^{b}$
}

How to cite this article:

Fernandes CSNN, Santos WBC, Moreira

WC, Vargas D, Nóbrega MPSS. Opinions on mental illness from the perspective of primary care nurses in Portugal. Rev Gaúcha Enferm. 2019:40:e20190034. doi: https://doi.org/10.1590/19831447.2019.20190034.

\footnotetext{
aniversidade Fernando Pessoa (UFP), Escola Superior de Saúde. Porto, Portugal.

- Universidade de São Paulo (USP), Escola de Enfermagem. São Paulo, São Paulo, Brasil.
}

\section{ABSTRACT}

Objective: To identify the opinions of primary care nurses regarding mental illness and the care provided to this population.

Methodology: Cross-sectional, quantitative study with the participation of 328 nurses of primary health care in Porto, Portugal. Data collected between April and August of 2018 through the scale "Opinions about Mental IIIness" and socio demographic and labor questionnaire. Descriptive and correlational statistics were applied.

Results: A total of $50 \%$ of the nurses presented positive opinions about the mental illness. Regarding the assistance provided in their unit of action, 53.4\% considered inadequate and 50.3\% recognized as adequate their knowledge about the role that primary health care has in assisting the person with mental illness.

Conclusion: Positive opinions and recognition of the importance of primary care to people with mental illness are important indicators for qualified mental health care outside the field of specialty.

Keywords: Mental health assistance. Mental health. Attitude of health personnel. Primary nursing.

\section{RESUMO}

Objetivo: Identificar as opiniões de enfermeiros de cuidados de saúde primários frente à doença mental e os cuidados prestados a essa população.

Metodologia: Estudo transversal, quantitativo, com participação de 328 enfermeiros de cuidados de saúde primários em Porto, Portugal. Dados coletados entre abril e agosto de 2018 por meio da escala "Opiniões acerca da Doença Mental" e questionário sócio demográfico e laboral. Aplicou-se estatística descritiva e correlacional.

Resultados: Um total de 50\% dos enfermeiros apresentaram opiniões positivas sobre a doença mental. Quanto à assistência disponibilizada em sua unidade de atuação, 53,4\% consideraram inadequadas e 50,3\% reconheceram como adequado o seu conhecimento sobre o papel que os cuidados de saúde primários têm na assistência à pessoa com doença mental.

Conclusão: As opiniões positivas e o reconhecimento da importância dos cuidados primários à pessoa com doença mental, são importantes indicadores para uma assistência de saúde mental qualificada fora do campo da especialidade.

Palavras-chave: Assistência à saúde mental. Saúde mental. Atitude do pessoal de saúde. Enfermagem primária.

\section{RESUMEN}

Objetivo: Identificar las opiniones de enfermeros de la atención primaria de la salud frente a la enfermedad mental y los cuidados prestados a esta población.

Metodología: Transversal, estudio cuantitativo, con la participación de 328 enfermeras en la atención primaria de la salud en Oporto, Portugal. Se recolectaron los datos entre abril y agosto de 2018 por medio de la escala "Opiniones sobre la Enfermedad Mental"y una encuesta sociodemográfica y laboral. Se aplicó la estadística descriptiva y correlacional.

Resultados: Un total de los 50\% de los enfermeros presentaron opiniones positivas sobre la enfermedad mental. En cuanto a la asistencia disponible en su unidad de actuación, el 53,4\% consideraron inadecuadas y el 50,3\% reconocieron como adecuado su conocimiento sobre el papel que tiene la atención primaria de la salud en la asistencia a la persona con enfermedad mental.

Conclusión: Las opiniones positivas y el reconocimiento de la importancia de la atención primaria a la persona con enfermedad mental son importantes indicadores para una asistencia de salud mental calificada fuera del campo de la especialidad. Palabras clave: Atención a la salud mental. Salud mental. Actitud del personal de salud. Enfermería primaria. 


\section{INTRODUCTION}

Mental illnesses are a major public health problem, with chronic tendencies and difficulties in the treatment ${ }^{(1)}$. Globally, it is estimated that more than 650 million people meet diagnostic criteria for mental illness, The most common are depression and anxiety ${ }^{(2)}$. Mental illnesses are often characterized by visible behavioral changes that can lead to negative attitudes, stereotypes and associated beliefs on the part of others ${ }^{(3-4)}$.

Stereotypes regarding these clinical conditions are associated with the belief that a group of people are dangerous and responsible for their own disease. Prejudice begins when one agrees with a stereotype and responds emotionally through certain behaviors, such as being afraid of all people with mental illness ${ }^{(5)}$. Several authors highlight the stigma attached to this point of view ${ }^{(6-9)}$. This stigma harms the person's biopsychosocial context, especially, his or her behavior towards the demand for health care ${ }^{(3)}$

In addition to the stigma of the general population, health professionals are also influenced by this view, and express more negative attitudes toward treatment progress for people with mental health problems compared to the general population $^{(10-12)}$. That is, effective treatment of the person with mental illness is hampered by negative beliefs that health professionals may have regarding the disease ${ }^{(1)}$.

Among health professionals, nurses take the most direct care to individuals with mental illness. Thus, they need to be aware that their attitudes influence the quality of care provided ${ }^{(11)}$. The positive attitude of nurses towards people with mental illness is an important indicator of results for the improvement of treatment and recovery, hence the relevance of understanding this phenomenon ${ }^{(3)}$.

Currently, mental health policies emphasize the concept of integrated care with other health services, especially at the level of primary health care ${ }^{(13)}$. The identification of mental health problems in primary health care has been inefficient and is lacking, mainly regarding interventions $^{(13)}$. Major reforms in this level of care must integrate mental health care, eliminate treatment gaps, and ensure that people receive the care they need. It is essential that primary care professionals are adequately prepared and encouraged to have attitudes, skills and competencies to assess, diagnose, treat, support and refer, if necessary, people with mental illness to specialized services ${ }^{(14)}$.

In a review of the literature, studies on the attitudes of primary care professionals were found, but nurses' opinions are not comprehensively contemplated. One Chinese study ${ }^{(15)}$ with primary care providers points to pessimistic and negative attitudes toward people with mental illness.
In Europe and Africa, notably in Finland ${ }^{(5)}$ and South Africa $^{(13)}$, the attitudes of primary care nurses are more positive in relation to this type of patient. Research comparing nurses from five European countries ${ }^{(16)}$, including Portugal, approaches the thematic attitude, but does not specifically highlight the reality of the attitudes of primary care nurses. It is noteworthy that none of these studies used the Opinions on Mental Illness (OMI) scale proposed in the present study.

Thus, data on the attitudes of Portuguese primary health care nurses about the mentally ill patients and their care experiences represent gaps that justify a study that makes it possible to determine the essence of the group's attitudes. Thus, this study aimed to identify the opinions of Portuguese primary health care nurses in the face of mental illness and the care provided to this population.

\section{METHODOLOGY}

This is a cross-sectional, descriptive, quantitative study with a non-probabilistic sample of 328 nurses. The inclusion criterion was to be a primary care nurse working in care and management, and the exclusion criterion was to be a nurse who performed exclusively managerial functions, in the city of Porto, Portugal. The participating units were: Public Health Unit (PHU), which works as a public health observatory in its geographical area; Shared Assistance Resource Units (SARU), which integrates specialized care services that provide services to all other units (e.g., social workers, psychologists, physiotherapists, occupational therapists, among others); Community Care Units (CCU), which provides home and community health care; Community Support Team in Palliative Care (CSTPC), which provides care to palliative patients and their families; the Family Health Units (FHU) and the Personalized Health Care Units (PHCU) that provide medical and nursing care

The invitation and informed consent form for study participation was made through a Google ${ }^{\circledast}$ form, sent by electronic mail, between April and August 2018. Data collection occurred during this same period, provided by a self-administered instrument available in Google Docs $^{\oplus}$ with variables related to demographic data (gender, age, marital status), work information (academic qualifications, training time, area of specialty and service). The Portuguese version of the "Opinions on Mental Illness (OMI)" scale, constructed by Struening and Cohen ${ }^{(17)}$, translated and validated by Oliveira ${ }^{(8)}$, Likert scale, composed of 51 items, which answers vary between 1 (completely agree) and 6 (completely disagree). 
ODM is organized in 5 dimensions: Authoritarianism; This factor represents an opinion on the person with mental illness as belonging to a class of inferior, irrecoverable persons who cannot be held accountable for their actions and should be controlled by society; Benevolence indicates a vision of paternalistic protection and protective kindness to these people, focusing on care, personal attention and material comfort; Ideology of Mental Hygiene assesses whether the respondent has an opinion of the person with mental illness as being similar to a "normal person" and can perform complex activities; Social Restriction, this factor represents a perspective of the person with mental illness as a danger to society, and should be restricted in some social domains; Interpersonal Etiology results from the belief that mental illness comes from bad interpersonal experiences lived in childhood ${ }^{(7-8)}$.

The minimum amplitude of the ODM is 51 and the maximum is 306 , with an average point of 178.5 . In this study, the Sten System ${ }^{(18)}$, which standardizes the results in scores of 1 to 10, Mean of 5.5 and Standard Deviation 0.5, was applied. Thus, the variations/domains of the scale that presented average points over 5 were considered as negative attitudes, and lower variations as positive attitudes.

The Cronbach's Alpha coefficient obtained by applying the OMI was 0.74 , close to the value of the original version $^{(8,17)}$. The data were treated using the Statistical Package for the Social Sciences (SPSS) program, version 24 for descriptive and correlational statistics. The
Wilcoxon Test, Mann-Whitney Test and Kruskal-Walli Test, and Fisher's exact test were applied. The $95 \%$ confidence level was used, which presented significance between the results when the $p$ value was $<0.05$.

The study was approved by the Ethics Committee of the Regional Health Administration of the City of Porto, Portugal, under opinion 155-2017.

\section{RESULTS}

Of the 328 participating nurses working in primary health care, 47.6\% ( $\mathrm{N}=156)$ worked in $\mathrm{FHU}, 32.3 \%(\mathrm{~N}=106)$ in $\mathrm{CCU}, 17.4 \%(\mathrm{~N}=57)$ in $\mathrm{PHCU}, 1.2 \%(\mathrm{~N}=4)$ in $\mathrm{PHU}, 0.9 \%$ $(\mathrm{N}=3)$ in CSTPC and $0.6 \%(\mathrm{~N}=2)$ in SARU. There was a predominance of females (84.8\%). As for the age group, the mean age was 42.7 years old (standard deviation $=7.9$ ). $R e-$ garding training time, most professionals had training time over 10 years (65.8\%).

Table 1 reports the characterization data of the sample, namely in relation to gender, age-years, marital status, academic qualifications, training time, specialty, area of specialty and performance services.

In Figure 1, the overall results of OMI application to the respondents showed a minimum amplitude of 106 and a maximum of 239, a mean of 117.4, close to the mean value of the scale (178.5), median of 177 and mode 178, the that it was possible to establish that about $50 \%$ of respondents present positive attitudes towards mental illness.

Table 1 - Distribution of nursing professionals according to the gender, age, marital status, schooling, training time, specialty, area of specialty, service, study Attitudes APS variables. Porto, Portugal, 2018 ( $n=328$ )

\section{Variables}

$\mathbf{N}$

$\%$

Mean

SD

Gender ( $\mathrm{N}=328)$

\begin{tabular}{|c|c|c|c|c|}
\hline $\begin{array}{l}\text { Male } \\
\text { Female }\end{array}$ & $\begin{array}{c}50 \\
278\end{array}$ & $\begin{array}{l}15.2 \\
84.8\end{array}$ & - & - \\
\hline Age - years $(N=328)$ & & & 42.7 & 7.9 \\
\hline \multicolumn{5}{|l|}{ Marital status ( $N=328)$} \\
\hline Single & 33 & 10.1 & & \\
\hline Married & 227 & 69.2 & & \\
\hline Marriage & 30 & 9.1 & & \\
\hline Separated & 4 & 1.2 & & \\
\hline Divorced & 31 & 9.5 & & \\
\hline Widow/widower & 3 & 0.9 & & \\
\hline
\end{tabular}

Academic qualifications ( $N=328)$ 


\section{Variables}

Bachelor's degree

Graduation

0.3

Master's degree

72.6

Doctor's degree

25.9

1.2

Time of training $(\mathrm{N}=328)$

$<1$ year

1 to 5 years

5 to 10 years

10 to 20 years

$>$ to 20 years

Specialty $(\mathrm{N}=328)$

\begin{tabular}{l} 
No \\
Yes \\
\hline Area of specialization $(\mathrm{N}=197)$
\end{tabular}

Community Nursing

Medical-Surgical Nursing

Rehabilitation Nursing

Child and Pediatric Health Nursing

Maternal and Obstetrical Health Nursing

Mental and Psychiatric Health Nursing

Service of action $(\mathrm{N}=328)$

$\mathrm{FHU}$

$\mathrm{PHCU}$

CCU

PHU

SARU

CSTPC

\section{1}

17.7

14.3

33.8

32.0

Source: Research data, 2018.

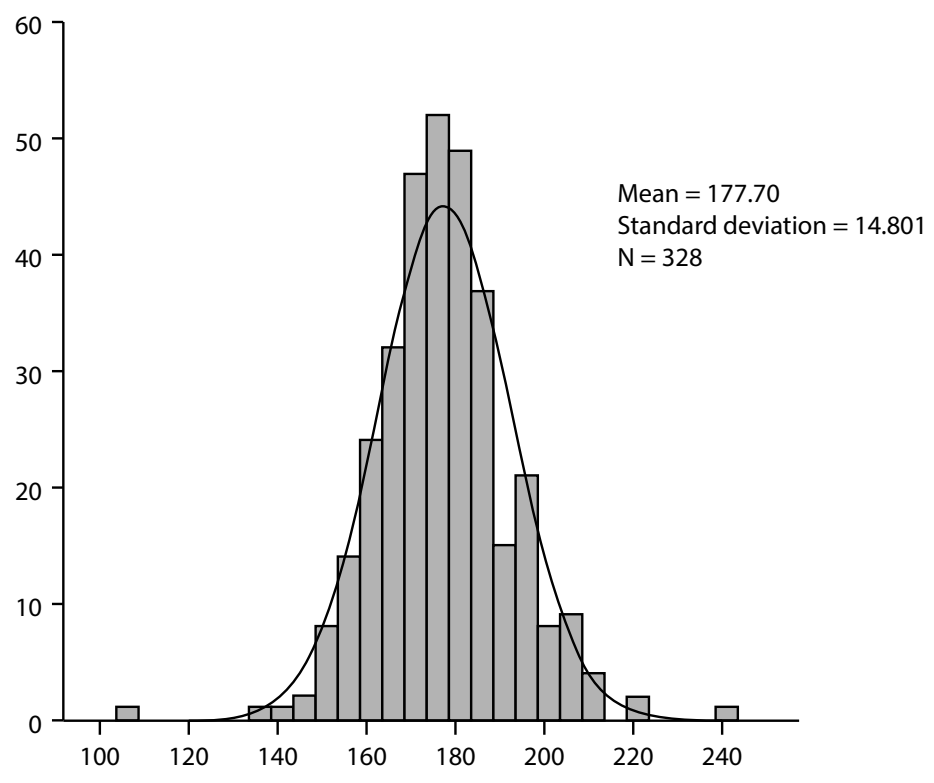

Figure 1- Histogram of distribution of the total score of the ODM scale 
Table 2 shows the values obtained in the various dimensions of the OMl after conversion through the Sten system. It is observed that the highest dimension was Benevolence with 7.7 average, followed by the Ideology of
Mental Hygiene dimension with 7.3 average. In the Authoritarianism dimension, the average obtained was of 4.1, and finally, in the Interpersonal Etiology and Social Restriction dimensions the average was of 3,4.

Table 2 - Averages of the dimensions of the OMI, Sten system, studyAPS attitudes. Porto, Portugal, 2018

\begin{tabular}{|c|c|c|c|c|c|}
\hline Scale Dimensions & Mean & Median & Minimum & Maximum & Standard Deviation \\
\hline Authoritarism & 4.1 & 4 & 1 & 9 & 1.3 \\
\hline Benevolence & 7.7 & 8 & 2 & 10 & 1.1 \\
\hline Mental Hygiene Ideology & 7.3 & 7.0 & 2 & 10 & 1.1 \\
\hline Social Restriction & 3.4 & 3.0 & 1 & 8 & 1.3 \\
\hline Interpersonal Etiology & 3.4 & 3.0 & 1 & 10 & 1.7 \\
\hline
\end{tabular}

Source: Research data, 2018.

Table 3 shows some correlations with the variables under study. It is observed that the overall value of the $\mathrm{OMI}$ positively correlated with the time of formation of the respondents $(p=0.019)$. Within the scope of the different dimensions of the OMI, the Mental Hygiene Ideology correlated with the type of unit $(p=0.008)$, the highest value being obtained in the CCU and the lowest value in the PHU.
The Social Restriction dimension correlated positively with academic qualifications ( $p=0.035)$, area of specialization $(p=0.026)$ and type of unit $(p=0.046)$. Within the area of specialization, the medical-surgical nurses were the ones who obtained the most negative opinions, and the mental health nurses obtained more positive opinions. Finally, the Interpersonal Etiology dimension was positively related to the training time $(p=0.019)$.

Table 3 - Correlations between the dimensions of the OMI and variables under study, study APS attitudes. Porto, Portugal, 2018

\begin{tabular}{|c|c|c|c|c|c|}
\hline Scale Dimensions & $\begin{array}{l}\text { Gender } \\
\text { P-value }\end{array}$ & $\begin{array}{c}\text { Academic } \\
\text { qualifications } \\
\text { P-value }\end{array}$ & $\begin{array}{c}\text { Area of } \\
\text { specialization } \\
\text { P-value }\end{array}$ & $\begin{array}{l}\text { Unit type } \\
\text { P-value }\end{array}$ & $\begin{array}{c}\text { Time of Training } \\
\text { P-value }\end{array}$ \\
\hline Total scale & 0.392 & 0.951 & 0.313 & 0.395 & $0.019^{*}$ \\
\hline Authoritarism & 0.072 & 0.795 & 0.525 & 0.198 & 0.149 \\
\hline Benevolence & 0.547 & 0.416 & 0.072 & 0.830 & 0.428 \\
\hline $\begin{array}{l}\text { Mental } \\
\text { Hygiene Ideology }\end{array}$ & 0.523 & 0.518 & 0.853 & $0.008^{*}$ & 0.208 \\
\hline Social restriction & 0.671 & $0.035^{*}$ & $0.026^{*}$ & $0.046^{*}$ & 0.069 \\
\hline Interpersonal Etiology & 0.557 & 0.942 & 0.614 & 0.510 & $0.019^{*}$ \\
\hline
\end{tabular}

Source: Research data, 2018.

*Significant correlation for $p<0.05$

Table 4 describes the views of the participants on the care provided to people with mental illness in the primary care setting. Regarding the assessment of health needs of people with mental illness in primary care, it was highlighted that $62.2 \%$ considered it inadequate, and 53.4\% considered the assistance provided inadequate in its unit of action.
Regarding the opinion on the knowledge about the assessment of health needs and comprehensive care of people with mental illness, $56.1 \%$ of the participants considered it appropriate. Finally, 50.3\% recognized as adequate their knowledge about the role of primary health care in the care of the mentally ill. 
Table 4 - Nurses' opinions on the care provided to the person with mental illness in the context of primary care, study APS attitudes. Porto, Portugal, 2018

\begin{tabular}{|c|c|c|c|c|}
\hline & $\begin{array}{c}\text { Very } \\
\text { inappropriate }\end{array}$ & Inadequate & Adequate & Very suitable \\
\hline $\begin{array}{l}\text { Assessment of the health needs of people with } \\
\text { mental illness in primary health care }\end{array}$ & $\begin{array}{l}9.8 \% \\
(\mathrm{~N}=32)\end{array}$ & $\begin{array}{c}62.2 \% \\
(N=204)\end{array}$ & $\begin{array}{l}25.0 \% \\
(\mathrm{~N}=82)\end{array}$ & $\begin{array}{c}3.0 \% \\
(\mathrm{~N}=10)\end{array}$ \\
\hline $\begin{array}{l}\text { Knowledge of health needs and } \\
\text { care assessment } \\
\text { of people with mental illness }\end{array}$ & $\begin{array}{c}3.4 \% \\
(\mathrm{~N}=11)\end{array}$ & $\begin{array}{c}36.6 \% \\
(N=120)\end{array}$ & $\begin{array}{l}56.1 \% \\
(\mathrm{~N}=184)\end{array}$ & $\begin{array}{c}4.0 \% \\
(\mathrm{~N}=13)\end{array}$ \\
\hline $\begin{array}{l}\text { Assistance to people with diseases } \\
\text { mental services provided in the service }\end{array}$ & $\begin{array}{l}11.3 \% \\
(\mathrm{~N}=37)\end{array}$ & $\begin{array}{l}53.4 \% \\
(N=175)\end{array}$ & $\begin{array}{l}33.2 \% \\
(N=10)\end{array}$ & $\begin{array}{l}2.1 \% \\
(\mathrm{~N}=7)\end{array}$ \\
\hline $\begin{array}{l}\text { Knowledge about the role of } \\
\text { primary health care in the } \\
\text { assistance to the person with mental illness }\end{array}$ & $\begin{array}{c}4.3 \% \\
(\mathrm{~N}=14)\end{array}$ & $\begin{array}{c}39.6 \% \\
(N=130)\end{array}$ & $\begin{array}{l}50.3 \% \\
(\mathrm{~N}=16)\end{array}$ & $\begin{array}{c}5.8 \% \\
(\mathrm{~N}=19)\end{array}$ \\
\hline
\end{tabular}

Source: Research data, 2018.

\section{DISCUSSION}

The results of this study showed that the opinion of primary care nurses in Porto, Portugal, regarding mental illness is slightly positive, and shows that part of the professionals interviewed still have a negative attitude towards this group, corroborating results obtained in other studies ${ }^{(5,13)}$.

Negative attitudes constitute a great barrier to recovery and social integration ${ }^{(12)}$. Such attitudes have been widely studied in several specialized health contexts, but with less frequency in primary health care ${ }^{(5,13)}$.

Regarding the different dimensions of the OMI scale, there is a discrepancy of values in the Authoritarianism and Benevolence dimensions. These two items emphasize, in the context of Authoritarianism, the archaic view that the mentally ill needs to be isolated from other patients, must remain locked, under surveillance, and within the framework of Benevolence it is translated to the view that the person with mental illness should be protected by means of protectionist, kind and patronizing resources ${ }^{(19)}$, interpreted as care and attention ${ }^{(7)}$, however, these attitudes are also understood as control and restriction of the community with these patients ${ }^{(8)}$.

The Social Restriction dimension, which assesses the opinion that people with mental illness should be socially restricted ${ }^{(19)}$, the high scores recorded in this study reflect intolerant attitudes regarding the person with mental illness, with emphasis on non-mental health nurses ${ }^{(19)}$. This fact occurs due to the lack of scientific knowledge about mental illness, which possibly generated this intolerance.
It was possible to find correlations between the variables of the study and the socio-demographic and labor data of the nurses regarding gender, academic skills, area of specialization, type of unit and time of formation, which have a direct relation with the positive or negative attitudes of the nurses.

When correlating the area of specialization and the type of unit with variables of the study, it was evidenced that the nurses who had more contact with people with mental illness, expressed more positive attitudes, also found in a study conducted with nursing students, which represents a possibility of reducing stigma against this population ${ }^{(7)}$.

In the Interpersonal Etiology dimension, the participants obtained high scores associated with the training time, reflecting a positive attitude. These results reinforce that academic skills acquired and the longer training time, allied to practice, can provide nurses with more diversified and sensitized environments, which leads them to show more benevolence, while not blaming poor interpersonal experiences of the person with mental illness ${ }^{(19)}$.

It is also worth noting that most nurses revealed that they did not know about the evaluation of the health needs and the integral care of people with mental illness. Similar results were obtained in an observational study with primary health care nurses regarding knowledge, attitudes and beliefs regarding the integration of mental health services in community settings, and the support or resistance to integrating mental health into care primary health care. The authors identified that nurses' attitudes and beliefs toward people with mental illness were positive, however, 
they reported having inadequate knowledge to manage care for these people ${ }^{(13)}$.

It is observed in the clinical practice of nurses of primary care the tendency that in order to make mental health, highly elaborate and robust actions are necessary, something that leads them to discredit their therapeutic potential and not to consider the scenario where the person is inserted as a resource which helps him reconfigure his life story. The nurse in this field must be prepared to go beyond the disease, and effectively enable the person with mental illness as well as his family to (re) constitute aspirations and achieve their goals ${ }^{(20)}$.

In addition, a multisectoral approach is needed to ensure that services support the mentally ill at different times in their lives, and enable them to exercise their fundamental rights, such as the right to employment, return to employment, housing, education, and the right to participate in community activities and programs, in addition to engaging in constructive activities ${ }^{(14)}$.

The findings of this study are consistent with the objectives of the mental health policy of professional investments beyond knowledge, among them the nurses, who need to be involved in oversight and processes that actively stand out and challenge their own beliefs and attitudes.

\section{- CONCLUSION}

Nurses' opinions are slightly positive in relation to the person with mental illness and are evidenced through protectionist conceptions and citizenship, placing them in a position of subjects of rights. However, nurses still maintain an authoritarian, exclusionary and accountable view of the individual for their own illness, visions that permeate the field of mental health in different realities.

In order to solidify and/or disrupt these realities, it is suggested to invest in the training/qualification of nurses that enhance therapeutic relationships and quality of care, fundamental to the person with mental disorder. New investigations to determine the type of training and to know which factors promote the change of the behaviors and attitudes of the nurses with respect to the person with mental illness are pertinent.

The study presents as limitations the fact that the data collection was conducted through Google Docs ${ }^{\circ}$ questionnaires, which makes the recognition of the total population unfeasible and the process mechanized, as well as those who responded to the study could be more sensitized with the subject.

\section{REFERENCES}

1. Tambag H. Effects of a psychiatric nursing course on beliefs and attitudes about nental IIIness. Int J Caring Sci. 2018 [cited 2018 Nov 4];11(1):420-6. Available from: $\quad$ http://www.internationaljournalofcaringsciences.org/docs/48_ tambag_original_11_1.pdf.

2. Hunter KN, Rice S, MacDonald J, Madrid J. What are the best predictors of opinions of mental illness in the Indian population? Int J Mental Health. 2014;43(2):35-51. doi: https://doi.org/10.2753/IMH0020-7411430203.

3. Neupane D, Dhakal S, Thapa S, Bhandari PM, Mishra SR. Caregivers' attitude towards people with mental illness and perceived stigma: a cross-sectional study in a tertiary hospital in Nepal. Plos One. 2016;11(6):e0158113. doi: https://doi.org/10.1371/journal.pone.0158113.

4. Granados-Gámez G, López Rodríguez MDM, Corral Granados A, MárquezHernández VV. Attitudes and beliefs of nursing students toward mental disorder: the significance of direct experience with patients. Perspect Psychiatr Care. 2017:53(2):135-43. doi: https://doi.org/10.1111/ppc. 12147.

5. Ihalainen-Tamlander N, Vähäniemi A, Löyttyniemi E, Suominen T, Välimäki M. Stigmatizing attitudes in nurses towards people with mental illness: a crosssectional study in primary settings in Finland. J Psychiatr Ment Health Nurs. 2016;23(67):427-37. doi: https://doi.org/10.1111/.jpm.12319.

6. Harrison CA, Hauck Y, Ashby R. Breaking down the stigma of mental health nursing: a qualitative study reflecting opinions from western australian nurses. J Psychiatr Ment Health Nurs. 2017;24(7):513-22. doi: https://doi.org/10.1111/ jpm. 12392.

7. Santos S, Soares M, Hirata A. Attitudes, knowledge, and opinions regarding mental health among undergraduate nursing students. Rev Esc Enferm USP. 2013;47(5):1195-102. doi: https://doi.org/10.1590/50080623420130000500026.

8. Oliveira S, Carolino L, Paiva A. Programa Saúde Mental Sem Estigma: efeitos de estratégias diretas e indiretas nas atitudes estigmatizantes. Rev Port Enferm Saúde Mental. 2012 [citado 2018 dez 10];(8):30-7. Disponível em: http://www.scielo.mec.pt/scielo.php?script=sci_arttext\&pid=\$164721602012000200005\&lng=pt.

9. Mancera KC, De Santacruz C, Salamanca MA. ["Accepting demented minds": opinion group, information and support on stigma of mental illness on Facebook]. Rev Colomb Psiquiat. 2014;43(3):139-45. Spanish. doi: https://doi. org/10.1016/j.rcp.2014.02.007.

10. Knaak S, Modgill G, Patten SB. Key ingredients of anti-stigma programs for health care providers: a data synthesis of evaluative studies. Can J Psychiatry. 2014 [cited 2018 Oct 10];59(10 Suppl 1):S19-S26. Available from: https:// www.ncbi.nlm.nih.gov/pmc/articles/PMC4213748/pdf/cjp-2014-vol59october-supplement-s19-s26.pdf.

11. Hsiao C-Y, Lu H-L, Tsai Y-F. Factors influencing mental health nurses' attitudes towards people with mental illness. Int J Ment Health Nurs. 2015;24(3):272-80. https://doi.org/10.1111/inm.12129.

12. Mårtensson G, Jacobsson JW, Engström M. Mental health nursing staff's attitudes towards mental illness: an analysis of related factors. J Psychiatr Mental Health Nurs. 2014;21(9):782-8. doi: https://doi.org/10.1111/jpm. 12145.

13. Dube FN, Uys LR. Integrating mental health care services in primary health care clinics: a survey of primary health care nurses' knowledge, attitudes and beliefs. S Afr Fam Pract. 2016;58(3):119-25. doi: http://doi.org/10.1080/20786190.2 016.1191747. 
14. World Health Organization (CH). Mental health policy, planning \& service development: integrating systems \& services, integrating people. Nursing matters: developing nursing resources for mental health. Geneva: WHO; 2007. Available from: https://www.who.int/mental_health/policy/services/ Nursing\%20Matters\%20Infosheet.pdf.

15. Ma Z, Huang H, Nie G, Silenzio VMB, Wei B. Attitudes towards mental illness among primary healthcare providers: a community-based study in rural China. Biomed Res Int. 2018:8715272. doi: https://doi.org/10.1155/2018/8715272.

16. Chambers ML, Guise V, Välimäki M, Botelho MA, Scott A, Staniuliené V, Zanotti R. Nurses' attitudes to mental illness: a comparison of a sample of nurses from five European countries. Int J Nurs Stud. 2010;47(3):350-62. doi: https://doi. org/10.1016/j.jinurstu.2009.08.008.
17. Struening, EL., Cohen, J. Factorial invariance and other psychometric characteristics offiveopinions aboutmental illnessfactors. EducatPsychol Measur. 1963;23(2):289-98. doi: https://doi.org/10.1177/001316446302300206.

18. Canfiled AA. The "sten" scale: a modified (-scale. Educ Psychol Meas. 1951;11(2):295-7. doi: https://doi.org/10.1177/001316445101100213.

19. Todor I. Opinions about mental illness. Procedia - Soc Behav Sci. 2013;82:20914. doi: https://doi.org/10.1016/j.sbspro.2013.06.247.

20. Fernandes CSNN, Nóbrega MPSS, Ângelo M, Torre MI, Chaves SC. Importance of families in care of individuals with mental disorders: nurses'attitudes. Esc Anna Nery. 2018; 22(4). https://doi.org/10.1590/2177-9465-ean-2018-0205.
- Corresponding author:

Carla Sílvia Neves da Nova Fernandes

E-mail: carlasilviaf@gmail.com
Received: 02.17.2019

Approved: 05.09.2019 